\title{
Short-term Storage of Plug-grown Bedding Plant Seedlings
}

\author{
M.P. Kaczperski and A.M. Armitage \\ Department of Horticulture, University of Georgia, Athens, GA 30602 \\ Additional index words. Petunia $\times$ hybrida, Salvia splendens, Viola $\times$ wittrockiana, \\ temperature, irradiance
}

Abstract. The effects of storage conditions before transplanting were examined for Petunia $\times$ hybrida Vilm. 'Supercascade Lilac', viola $\times$ wittrockiana Gams 'Universal Beaconsfield', and Salvia splendens F. Sellow ex Roem. \& Schult 'Red Hot Sally'. Plug grown seedlings were stored for $0,7,14$, or 21 days at 5 or $10 \mathrm{C}$ and with continuous irradiance levels from incandescent bulbs at 0,2 , or $12 \mu \mathrm{mol} \cdot \mathrm{m}^{-2} \cdot \mathrm{s}^{-1}$. A second group was stored at $18 \mathrm{C}$ with irradiance from fluorescent bulbs at $105 \mu \mathrm{mol} \cdot \mathrm{m}^{-2} \cdot \mathrm{s}^{-1}$ and a 16-hour photoperiod for the same durations. Temperature was more important than irradiance in maintaining a commercially acceptable plant during the storage period. Petunia and pansy could be stored successfully for 21 days at 5 or $10 \mathrm{C}$ with no appreciable loss of quality; salvia could be stored for a minimum of 14 days. Seedlings of all species elongated excessively when stored $>7$ days at $18 \mathrm{C}$ and $105 \mu \mathrm{mol} \cdot \mathrm{m}^{-2} \cdot \mathrm{s}^{-1}$ irradiance. After 14 days of storage, petunias stored at $18 \mathrm{C}$ flowered sooner than those stored at 5 or $10 \mathrm{C}$ but time in a production environment (days to flower - days in storage) was similar for petunias stored at 5 or $18 \mathrm{C}$.

The bedding plant industry differs from other floricultural industries in that bedding plant producers often have no predetermined marketing date for their product (Carlson et al., 1992). A bedding plant producer only knows in general terms when the crop will be marketed. Although a target date is selected, it may be altered during the growing process to meet market demand. A period of good weather in the spring increases market demand for bedding plants, and periods of inclement weather delay the marketing date for the crop by several days or even weeks. A bedding plant producer must be flexible to manage this fluctuating marketing date.

One of the tools available to the grower to increase efficiency of crop production is the plug. The use of plugs in the production of bedding plant seedlings has greatly in-

Received for publication 8 July 1991. Accepted for publication 13 Jan. 1992. We thank Ball Seed Co. for supplying plant material for this project. The cost of publishing this paper was defrayed in part by the payment of page charges. Under postal regulations, this paper therefore must be hereby marked advertisement solely to indicate this fact. creased over the past 20 years (Lieberth, 1989). The plug industry has advanced to the point where numerous producers specialize in plugs to sell to other growers. Great demand during a short marketing period is a problem with plug production. Plug producers would benefit from a system of storing plugs for short periods to increase total output during the marketing period. Bedding plant producers often cannot transplant everything when the plugs arrive and would similarly benefit from such a storage system. The purpose of this experiment was to examine the influence of low temperature and irradiance on plug storage and the effects on subsequent plant quality.

Transplantable plugs of Petunia $\times$ hybrida 'Supercascade Lilac', viola $\times$ wittrockiana 'Universal Beaconsfield' and Salvia splendens 'Red Hot Sally' were obtained from Ball Seed Co. (Chicago). Seedlings were produced in \#390 plug trays (4.0-ml capacity). Ten plants were selected at random from each cultivar as control plants and planted in 10-cm (0.52-liter) plastic pots filled with a peat lite mix (Fafard Inc., Springfield, Mass.). These 10 plants were not stored but placed 
Table 1. Days to flower for Petunia $\times$ hybrida 'Supercascade Lilac' in response to storage temperature, irradiance, and storage period.

\begin{tabular}{lccr}
\hline \hline $\begin{array}{l}\text { Temp }\left({ }^{\circ} \mathrm{C}\right) / \\
\text { irradiance } \\
\left(\mu \mathrm{mol} \cdot \mathrm{m}^{-2} \cdot \mathrm{s}^{-1}\right)\end{array}$ & \multicolumn{3}{c}{ Storage period (days) } \\
\cline { 2 - 4 } & $\mathbf{7}$ & 14 & 21 \\
\hline $5 / 0$ & 72 & 77 & 89 \\
$5 / 2$ & 70 & 78 & 86 \\
$5 / 12$ & 70 & 77 & 81 \\
$10 / 0$ & 77 & 90 & 91 \\
$10 / 2$ & 83 & 86 & 88 \\
$10 / 12$ & 79 & 87 & 86 \\
$18 / 105$ & 70 & 71 & 72 \\
Dunnett's value & 3 & 3 & 4 \\
\hline
\end{tabular}

zTreatment means in each column differing from the control by more than the Dunnett's value are significantly different from the control $(P=0.05)$. The nonstored control required 71 days to flower.

Table 2. Days in production environment for $P e$ tunia $\times$ hybrida 'Supercascade Lilac' in response to storage temperature, irradiance, and storage period.

\begin{tabular}{lccr}
\hline \hline \multirow{2}{*}{$\begin{array}{l}\text { Temp }\left({ }^{\circ} \mathrm{C}\right) / \\
\text { irradiance } \\
\left(\mu \mathrm{mol} \cdot \mathrm{m}^{-2} \cdot \mathrm{s}^{-1}\right)\end{array}$} & \multicolumn{3}{c}{ Storage period (days) } \\
\cline { 2 - 4 } & 7 & 14 & 21 \\
\hline $5 / 0$ & 65 & 63 & 68 \\
$5 / 2$ & 63 & 64 & 65 \\
$5 / 12$ & 63 & 63 & 60 \\
$10 / 0$ & 70 & 76 & 70 \\
$10 / 2$ & 76 & 72 & 67 \\
$10 / 12$ & 72 & 73 & 65 \\
$18 / 105$ & 70 & 71 & 72 \\
Dunnett's value $^{2}$ & 3 & 3 & 4 \\
\hline
\end{tabular}

${ }^{z}$ Treatment means in each column differing from the control by more than the Dunnett's value are significantly different from the control $(P=0.05)$. The nonstored control required 71 days in production environment.

Table 3. Days to flower for Viola $\times$ wittrockiana 'Universal Beaconsfield' in response to storage temperature, irradiance, and storage period.

\begin{tabular}{lrrr}
\hline \hline $\begin{array}{l}\text { Temp }\left({ }^{\circ} \mathrm{C}\right) / \\
\text { irradiance } \\
\left(\mu \mathrm{mol} \cdot \mathrm{m}^{-2} \cdot \mathrm{s}^{-1}\right)\end{array}$ & \multicolumn{3}{c}{ Storage period (days) } \\
\cline { 2 - 4 } & \multicolumn{1}{c}{7} & 14 & 21 \\
\hline $5 / 0$ & 99 & 112 & 119 \\
$5 / 2$ & 103 & 110 & 121 \\
$5 / 12$ & 99 & 115 & 119 \\
$10 / 0$ & 98 & 110 & 115 \\
$10 / 2$ & 97 & 106 & 110 \\
$10 / 12$ & 94 & 106 & 114 \\
$18 / 105$ & 93 & 98 & 102 \\
Dunnett's value & 4 & 4 & 4 \\
\hline
\end{tabular}

Treatment means in each column differing from the control by more than the Dunnett's value are significantly different from the control $(P=0.05)$. The nonstored control required 91 days to flower.

in a growth chamber under conditions simulating a commercial production environment. Photosynthetic photon flux (PPF) was provided by fluorescent and incandescent bulbs (input wattage 85:15, respectively) at an intensity of $105 \mu \mathrm{mol} \cdot \mathrm{m}^{-2} \cdot \mathrm{s}^{-1}$ and a $16-$ $\mathrm{h}$ photoperiod. Temperature was maintained at $18 \pm 3 \mathrm{C}$. In the initial irrigation following transplanting, $300 \mathrm{ml}$ of a commercial fertilizer solution consisting of a plant starter fertilizer (Peter's 9N-45P-15K, 6 g.liter ${ }^{-1}$ ) and trace element mix (Peter's S.T.E.M.,

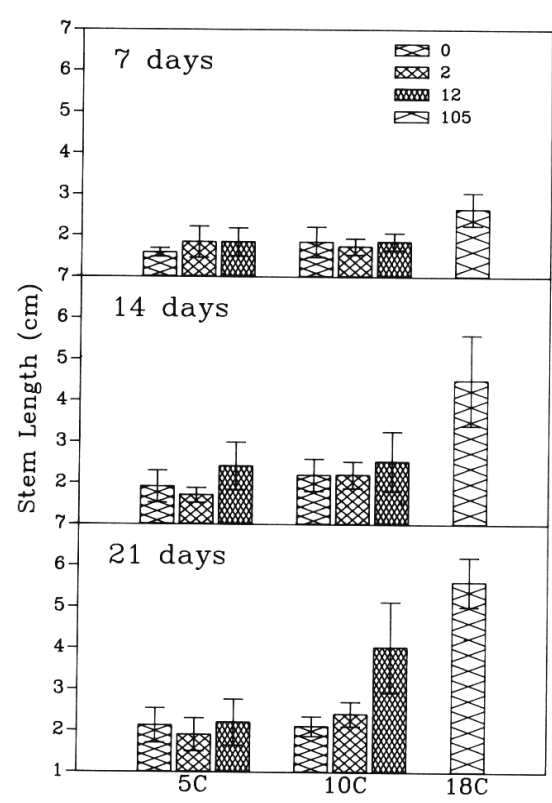

Fig. 1. Main stem length of Petunia $\times$ hybrida 'Supercascade Lilac' stored at 5 or $10 \mathrm{C}$ at 0,2 , or $12 \mu \mathrm{mol} \cdot \mathrm{m}^{-2} \cdot \mathrm{s}^{-1}$ or at $18 \mathrm{C}$ and 105 $\mu \mathrm{mol} \cdot \mathrm{m}^{-2} \cdot \mathrm{s}^{-1}$ for 7,14 , or 21 days. Bars indicate SE.

0.6 g.liter ${ }^{-1}$ ) (W.R. Grace, Fogelsville, Pa.) were applied to each pot. Plants were irrigated as necessary to prevent water stress and fertilized with $10.7 \mathrm{~mm} \mathrm{~N}$ and $3.18 \mathrm{~mm}$ $\mathrm{K}$ from $\mathrm{Ca}\left(\mathrm{NO}_{3}\right)_{2}$ and $\mathrm{KNO}_{3}$ at each irrigation and were grown to flower. Remaining plants were not transplanted but divided into seven groups and stored. Storage was at 5 or $10 \mathrm{C}$ under continuous irradiances of 0,2 , or $12 \mu \mathrm{mol} \cdot \mathrm{m}^{-2} \cdot \mathrm{s}^{-1}$ from $100-\mathrm{W}$ incandescent bulbs or in the growth chamber with the previously potted plants to simulate greenhouse storage in a production environment. After 7, 14, or 21 days, 10 plants from each variety were randomly selected from each storage regime and evaluated for suitability as a transplant. Measures of suitability were based on mainstem length and average internode length. Mainstem or internode elongation was considered to be a reduction in quality. Plants were then transplanted similarly to the control group, which were not stored, and grown to flower in the production environment growth chamber. At flowering, days to flower was evaluated for all plants. Days to flower was defined as the number of days from sowing the seed to anthesis. Differences between the stored and nonstrored plugs were determined using Dunnett's procedure.

Petunia and pansy seedlings could be successfully stored 21 days at 5C. In general, since both species grow best at low temperatures (Kaczperski et al., 1991; Koranski, 1988), storage at $5 \mathrm{C}$ was not detrimental to plant growth. Salvia, however, performs best in the greenhouse at higher temperatures (Kaczperski and Carlson, 1989), and the low temperatures in storage resulted in leaf yellowing and loss.

Petunia growth is slow at low tempera- tures, but growth is still evident at 10C (Kaczperski et al., 1991). Petunia seedlings stored well at 5C under any irradiance with little stem elongation (Fig. 1). However, at $10 \mathrm{C}$ and $12 \mu \mathrm{mol} \cdot \mathrm{m}^{-2} \cdot \mathrm{s}^{-1}$ irradiance the petunia stems elongated when stored $>14$ days. When stored in a production environment at $18 \mathrm{C}$ and $105 \mu \mathrm{mol} \cdot \mathrm{m}^{-2} \cdot \mathrm{s}^{-1}$ irradiance, the seedlings elongated after 7 days of storage and became commercially unacceptable.

Pansies stored as well as petunias at $5 \mathrm{C}$ for up to 21 days with no stem elongation (Fig. 2). At 10C, seedlings were variable in size after 14 days and were not commercially acceptable. Plants in the production environment elongated during the first 7 days of storage. Pansies have previously been stored successfully for several months at low temperatures with no loss of quality (Lange et al., 1991). However, the variety used in our experiment did not behave in that manner. 'Universal Beaconsfield' performs poorly under less than optimum environmental conditions, perhaps accounting for its poor performance-under storage at 10 and 18C (D.S. Koranski, personal communication).

Salvia seedlings did not elongate significantly when stored at 5C (Fig. 3). These plants could be stored up to 14 days at $5 \mathrm{C}$ without seedling deterioration. Between 14 and 21 days of storage at 5 or $10 \mathrm{C}$, salvia receiving no irradiance incurred losses from a botrytis infection. Those stored under 2 or $12 \mu \mathrm{mol} \cdot \mathrm{m}^{-2} \cdot \mathrm{s}^{-1}$ irradiance at either temperature were not infected by botrytis, but the crowded spacing induced leaf chlorosis and abscission. Similar results were obtained in plants stored in the production environment.

Days to flower in petunia was affected by days in storage (Table 1); the longer the storage period, the longer they took to flower. Plants stored in the plug flat in the production environment flowered in the same number of days as those that were not stored. Plants kept at 5 and 10C were delayed in flowering by up to 21 days, depending on length of storage time. However, days in the production environment (days to flower days in storage) was similar for plants stored at $10 \mathrm{C}$ and those not stored (Table 2). Although petunia seedlings stored at $10 \mathrm{C}$ for 14 days were delayed in flowering by $\approx 14$ days, they spent the same number of days in the production environment as the petunias not stored. Similar results were found with geranium (White and Quatchak, 1985).

The petunia seedlings stored at $5 \mathrm{C}$ required less time in the production environment than those not stored (Table 2). Even though days to flower was delayed at $5 \mathrm{C}$, time in the production environment was reduced by up to 10 days. Petunia is a longday plant, and a cold period can substitute for long days in some long-day plants (NappZinn, 1984). A similar process may be occurring in the petunias kept at $5 \mathrm{C}$, resulting in a reduction in days in the production environment.

Within a given storage temperature, days to flower in petunia was longest for the plants stored in darkness (Table 1). An exception 


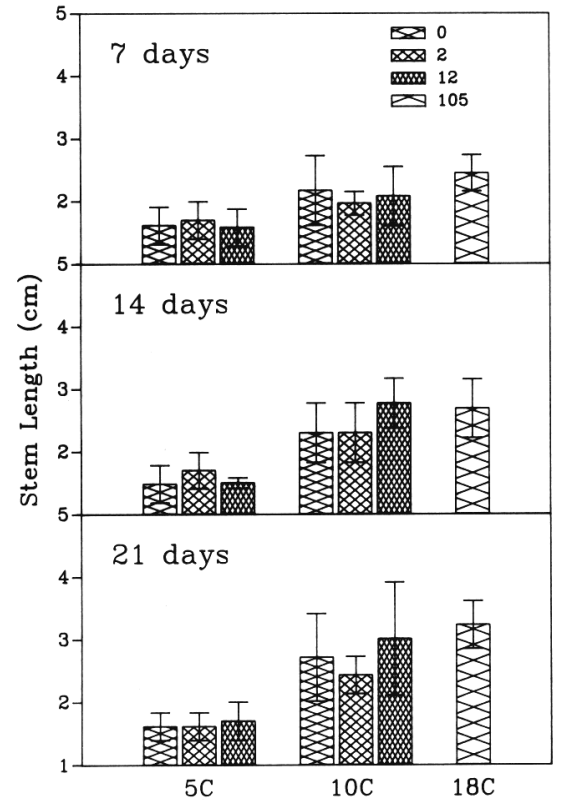

Fig. 2. Main stem length of Viola $\times$ wittrockiana 'Universal Beaconsfield' stored at 5 or $10 \mathrm{C}$ at 0,2 , or $12 \mu \mathrm{mol} \cdot \mathrm{m}^{-2} \cdot \mathrm{s}^{-1}$ or at $18 \mathrm{C}$ and 105 $\mu \mathrm{mol} \cdot \mathrm{m}^{-2} \cdot \mathrm{s}^{-1}$ for 7,14 , or 21 days. Bars indicate SE.

Table 4. Days to flower for Salvia splendens 'Red Hot Sally' in response to storage temperature, irradiance, and storage period.

\begin{tabular}{lcrr}
\hline \hline $\begin{array}{l}\text { Temp }\left({ }^{\circ} \mathrm{C}\right) / \\
\text { irradiance } \\
\left(\mu \mathrm{mol} \cdot \mathrm{m}^{-2} \cdot \mathrm{s}^{-1}\right)\end{array}$ & \multicolumn{3}{c}{ Storage period (days) } \\
\cline { 2 - 4 } & 7 & 14 & 21 \\
\hline $5 / 0$ & 91 & 97 & 100 \\
$5 / 2$ & 94 & 94 & 102 \\
$5 / 12$ & 89 & 96 & 106 \\
$10 / 0$ & 84 & 94 & 93 \\
$10 / 2$ & 84 & 96 & 98 \\
$10 / 12$ & 81 & 91 & 98 \\
$18 / 105$ & 74 & 77 & 76 \\
Dunnett's value & 4 & 4 & 4 \\
\hline
\end{tabular}

'Treatment means in each column differing from the control by more than the Dunnett's value are significantly different from the control $(P=0.05)$. The nonstored control required 73 days to flower.

was storage at $10 \mathrm{C}$ for 7 days. A 9-day decrease in days to flower was observed for petunias stored at $12 \mu \mathrm{mol} \cdot \mathrm{m}^{-2} \cdot \mathrm{s}^{-1} \mathrm{com}$ pared with those kept in darkness at $5 \mathrm{C}$. Irradiances used may have allowed the illuminated plants to perceive long days. The dark-stored plants would have perceived short days, which would have delayed their flowering.

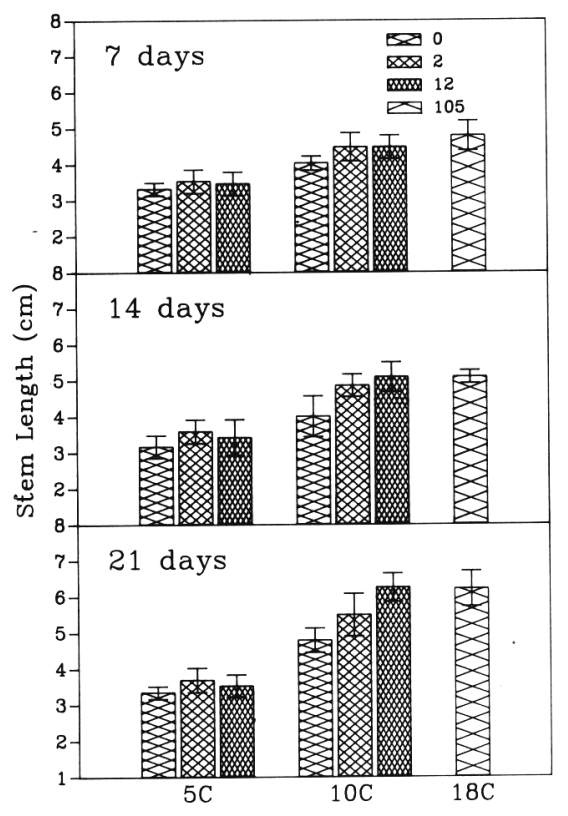

Fig. 3. Main stem length of Salvia splendens 'Red Hot Sally' stored at 5 or $10 \mathrm{C}$ at 0,2 , or $12 \mu \mathrm{mol} \cdot \mathrm{m}^{-2} \cdot \mathrm{s}^{-1}$ or at $18 \mathrm{C}$ and 105 $\mu \mathrm{mol} \cdot \mathrm{m}^{-2} \cdot \mathrm{s}^{-1}$ for 7,14 , or 21 days. Bars indicate SE.

Days to flower in pansy was also delayed by increasing days in storage (Table 3); however, no decreased time in the production environment of stored plants was observed as in petunia. Exclusive of days in storage, stored pansies flowered in a similar amount of time or were delayed by up to 10 days when compared with nonstored plants. Delays in flowering in stored pansy seedlings were also reported by Al-Hemaid and Koranski (1990) and Koranski et al. (1989). Storage in the production environment also delayed flowering. Keeping plants in the plug trays too long has been attributed to delayed flowering in geranium (Pelargonium $\times$ hortorum L.H. Bailey) (Holcomb and White, 1987; Hopper and Carlson, 1985).

Flowering in salvia was delayed more by storage for 7 days at $5 \mathrm{C}$ than at 10C (Table 4). However, as storage time increased, the difference in days to flower due to storage temperature became less. Time to flowering at either low temperature was much longer than for those salvia stored in the production environment. However, since the salvia stored in the production environment elongated substantially (Fig. 3), storage was more successful at the lower temperatures.
Irradiance during low-temperature storage had little effect on days to flower in salvia through 14 days (Table 4). After 21 days of storage, salvia stored at $12 \mu \mathrm{mol} \cdot \mathrm{m}^{-2} \cdot \mathrm{s}^{-1}$ flowered later than those stored in the dark. The variety we used showed slight acceleration of flowering under short days (Kaczperski and Carlson, 1989), and the darkstored plants may have been initiated earlier because of continuous short days.

Low temperatures can be used to store plugs of petunia, pansy, and salvia if the need arises. Plants may be kept at 5C at any of the irradiances examined; petunia and pansy can be kept for 21 days, salvia for 14. Higher temperatures caused deterioration of the plugs, rendering them unusable. Petunias may actually benefit from the cold storage, resulting in less time in the greenhouse than plants not stored.

\section{Literature Cited}

Al-Hemaid, A.I. and D.S. Koranski. 1990. Temperature, transplant time and plug size effects on growth and development of pansy, petunia, vinca and impatiens. HortScience 25:1159. (Abstr.)

Carlson, W.H., M.P. Kaczperski and E.M. Rowley. 1992. Bedding plants, p. 513-550. In: R.A. Larson (ed.). Introduction to floriculture. Academic, N.Y.

Holcomb, E.J. and J.W. White. 1987. Duration in plug cells affects growth and flowering of geraniums. Applied Agr. Res. 2:350-353.

Hopper, D.A. and W.H. Carlson. 1985. Plugs: less space, less time. Grower Talks 48(9):4854.

Kaczperski, M.P. and W.H. Carlson. 1989. Producing salvia-a commercial grower's guide. Mich. State Univ. Coop. Ext. Bul. E-1663. East Lansing, Mich.

Kaczperski, M.P., W.H. Carlson, and M.G. Karlsson. 1991. Growth and development of Petunia $\times$ hybrida as a function of temperature and irradiance. J. Amer. Soc. Hort. Sci. 116:232-237

Koranski, D.S. 1988. How to produce plugs of the big five. Grower Talks 51(9):22-23.

Koranski, D., P. Karlovich, and A. Al-Hemaid. 1989. The latest research on holding and shipping plugs. Grower Talks 53(8):72-79.

Lange, N., R. Heins, and W. Carlson. 1991. Store plugs at low temperatures. Greenhouse Grower 9(1):22-28

Lieberth, J.A. 1989. Over 3 billion sold. Greenhouse Grower 7(11):12-13.

Napp-Zinn, K. 1984. Light and vernalization, p. 75-88. In: D. Vince-Prue, B. Thomas, and K.C. Cockshull (eds.). Light and the flowering process. Academic, N.Y.

White, J.W. and D.J. Quatchak. 1985. Cool storage of plug grown geranium seedlings. Grower Talks 48(10):68-71. 